\title{
Flying past tipping points
}

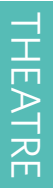

"The Golden toad. The West African black rhino. The Javan tiger. The crested sheldrake." At the Secretariat of the 2009 Copenhagen Climate conference, a harassed bureaucrat at the 'Extinction Desk' calls out each species as its file appears on his desk for processing. The files arrive thick and fast in trolleys and bundles in the arms of exhausted workers, and soon the teetering piles have buried the extinction worker, as his voice continues the haunting list of animals.

So begins a most extraordinary and mesmerizing outdoor performance. Wired Aerial Theatre's As the World Tipped features half a dozen workers from the Intergovernmental Panel on Climate Change struggling to carry on with business as usual, while the world around them literally tips towards disaster. The stage, suspended in the night sky by cranes, is cranked gradually up to the vertical, causing the office furniture, files and trolleys to slide off-stage to oblivion. Finally, the actors are left, scrabbling and flailing in tiny human forms against the inhospitable backdrop of catastrophic climate change projected around them. The stage becomes a vast screen displaying auteur Yann Arthus-Bertrand's stunning aerial images from his 2009 climate change-inspired documentary, Home. Wildfires rage, choking the actors, who are then struggling for breath amidst rising floodwaters. A sequence of dramatic weather headlines - pitiful victims of climate change in the developing world and destroyed landscapes - is seamlessly interwoven with the physically present performers, who dangle acrobatically on ropes and pulleys as a three-dimensional component of the filmed planet.

As the World Tipped was written and directed by Australian Nigel Jamieson, most notable as artistic director of the opening ceremony for the 2000 Sydney Olympics, and the performance has been shown at a series of festivals and outdoor events across the UK. Wired Aerial Theatre's artistic

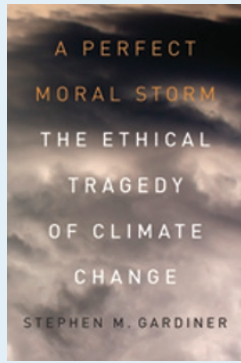

WIIGEO SENTINELS

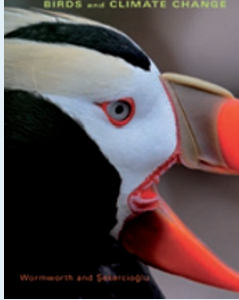

\section{A Perfect Moral Storm: The Ethical Tragedy of Climate Change}

Stephen M. Gardiner

OXFORD UNIV. PRESS: 2011. 512 PP. $€ 22.50$

Describing our inaction on climate change as an ethical failure, philosopher Stephen Gardiner, argues that our stasis stems from wilful selfdeception. He explains how this enables the cost of climate change to fall on the poor and weak, and to be passed on to future generations. Gardiner concludes that we must wake up to this ethical failure and demand more of our institutions, our leaders and ourselves.

\section{Winged Sentinels: Birds and Climate Change} Janice Wormworth and Cağan H. Sekercioğlu CAMBRIDGE UNIV. PRESS: 2011. 296 PP. $€ 24.99$

This book is richly illustrated with examples of how birds are responding to climate change, and argues that these represent early warning signs that we would do well to heed. The authors, science writer Janice Wormworth and biologist C,ağan Șekercioğlu, provide fascinating insights into the many ways that climate change is impacting birdlife and what we can do to help them adapt.

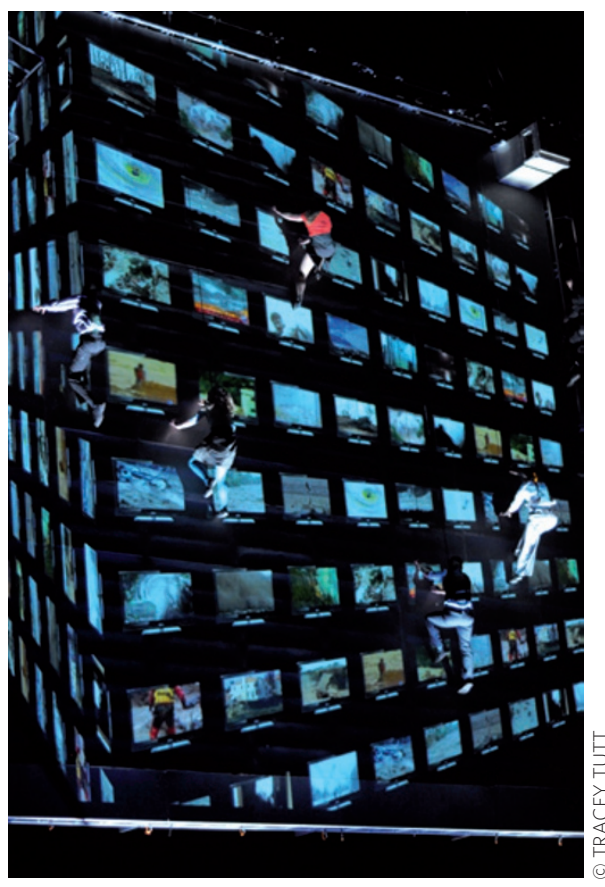

directors Wendy Hesketh-Ogilvie and Jamie Ogilvie came up with the ambitious stage-in-the-sky idea, which allows the precarious nature of environmental tipping points to be realized at such an awesome scale. Grumbles by some audience members included criticism that the piece was too depressing, the environmental catastrophe rendered too graphic and the message too negative, but as the accumulating evidence shows, the performance was an accurate reflection of the state of our world. If anything, the final message, that we can still avoid catastrophe, was one based on hope rather than science.

Perhaps fortunately for Jamieson, the international climate meetings subsequent to Copenhagen have also yielded little government action on climate change mitigation, meaning his beautiful production holds enduring relevance.

\section{REVIEWED BY GAIA VINCE}

\section{As the World Tipped, a Wired Aerial}

Theatre production, written and directed by Nigel Jamieson. Performance reviewed at Mile End Park, London, 25 June 2011. Future performance dates can be found at www.astheworldtipped.com 